\title{
CURRENT RATIO, DER DAN EARNING PER SHARE TERHADAP BETA SAHAM PERUSAHAAN PROPERTY DAN REAL ESTATE
}

\author{
Didin Fatihudin ${ }^{1}$, Achmad Al Irfan ${ }^{2 *}$ \\ Program Studi Manajemen Fakultas Ekonomi dan Bisnis, Universitas Muhammadiyah Surabaya \\ *) al.irfan33@gmail.com
}

\section{Informasi Artikel}

Draft awal: September 2021

Revisi : September 2021

Diterima : September 2021

Available online: September 2021

Keywords: Debt to Equity Ratio (DER), Currentu Ratio, Earning per Share, BETA Saham, Properti \& Real Estate

Tipe Artikel : Research paper

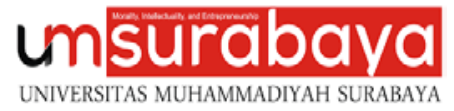

Diterbitkan oleh Universitas Muhammadiyah Surabaya

\section{ABSTRACT}

This research is entitled The Effect of Debt to Equity Ratio (DER), Current Ratio, and Earning Per-Share on Stock Beta (Case Study of Property and Real Estate Companies Listed on the IDX 2010-2019 Period). This research method uses multiple linear regression analysis with data processing using the tool Eviews 10 program. The sampling method of this research uses purposive sampling technique. The results showed that simultaneous Debt to Equity Ratio, Current Ratio, and Earning Per Share had no effect on share beta. The results of the $t$ test show that the variables Debt to Equity Ratio, Current Ratio, and Earning Per Share partially have no effect on share beta with a significance level of $4 \%, 49 \%$, and $50 \%$.

Penelitian ini berjudul Pengaruh Debt to Equity Ratio (DER), Current Ratio, dan Earning Per-Share Terhadap Beta Saham (Studi Kasus Pada Perusahaan Properti dan Real Estat Yang Terdaftar Di BEI Periode 20102019). Metode penelitian ini menggunakan analisis regresi linier berganda dengan pengolahan data menggunakan alat bantu program Eviews 10. Metode pengambilan sampel dalam penelitian ini menggunakan teknik purposive sampling. Hasil penelitian menunjukkan bahwa secara simultan Debt to Equity Ratio, Current Ratio, dan Earning Per Share tidak berpengaruh terhadap beta saham. Hasil uji t menunjukkan bahwa variabel Debt to Equity Ratio, Current Ratio, dan Earning Per Share secara parsial tidak berpengaruh terhadap beta saham dengan tingkat signifikansi $4 \%$, $49 \%$, dan $50 \%$.

\section{PENDAHULUAN}

Risiko sistematis merupakan risiko yang tidak dapat diminimalkan dengan melakukan diversifikasi, karena fluktuasi risiko ini dipengaruhi oleh faktor-faktor makro yang dapat mempengaruhi pasar secara keseluruhan. Sedangkan risiko tidak sistematis merupakan risiko yang dapat diminimalkan dengan melakukan diversifikasi. Dalam mengukur berbagai fluktuasi dari return-return suatu sekuritas atau portofolio dalam suatu periode tertentu, hal ini dinamakan volatilitas (volatility). Maka dengan ini pengukuran dilakukan menggunakan perhitungan beta. Karena pada dasarnya beta merupakan suatu pengukuran risiko sistematik return suatu sekuritas atau return portofolio terhadap return pasar.

Proses perhitungan beta juga merupakan pengukur risiko sistematik (systematic risk) dari suatu sekuritas atau portofolio relatif terhadap risiko pasar. Jika fluktuasi return-return sekuritas atau portofolio ditinjau secara statistik mengikuti fluktuasi dari return-return pasar, maka beta dari sekuritas atau portofolio tersebut dinyatakan bernilai 1 . Beta sama dengan 1 juga menunjukan bahwa jika return pasar bergerak naik (turun), return sekuritas atau portofolio juga bergerak naik (turun) sama besarnya mengikuti return pasar (Hartono, 2016:433). Hal ini juga serupa dengan apa yang diungkapkan oleh Fahmi (2014:433), bahwa beta menunjukan hubungan atau gerakan antara saham dan pasarnya atau bias disebut dengan saham secara keseluruhan. Beta juga diartikan sebagai risiko saham sistematis .

Penelitian ini berada pada objek perusahaan-perusahaan yang bergerak di sektor property dan real estate. Pada bidang ini tentunya telah sedia sejak lama, dikarenakan sektor ini merupakan bidang bisnis yang ada di Indonesia dan terus berkembang. Sektor ini diambil oleh peneliti karena pada objek perusahaan yang 
tergabung didalam sektor property dan real estate secara terdaftar oleh BEI, dinilai salah satu memiliki tingkat volatilitas yang tinggi dari beberapa sektor. Pernyataan ini diperkuat dengan adanya tingkat volatilitas harga saham sektor property dan real estate yang sampai pada angka 62,24\%. Sedangkan jika dibandingan dengan sektor lain, misalnya pada sektor agriculture yang mencapai 39,04\% dan pada sektor mining dengan angka $62,23 \%$. Hal ini menunjukan bahwa cukup tinggi tingkat volatilitas sektor property dan real estate dengan sektor lainnya. Indeks harga saham pada pasar yang cenderung fluktuatif bisa disinyalir memiliki tingkat risiko yang lebih tinggi. Melakukan penelitian beta saham pada sektor ini memang memberikan nilai guna bagi yang berkepentingan di bidang tersebut (Jazuli dkk, 2016:64)

Pertumbuhan harga properti komersial melambat pada triwulan IV-2019. Hal tersebut sebagaimana tercermin dari Indeks Harga Properti Komersial yang tercatat tumbuh $0,32 \%$ (years of years) pada triwulan IV-2019, melambat dari $1,37 \%$ (years of years) pada triwulan sebelumnya. Kenaikan harga terutama disebabkan oleh kenaikan harga pada segmen perkantoran dan lahan industri, sedangkan pada segmen lainnya seperti apartemen sewa, hotel, convention hall mengalami penurunan. Kenaikan harga pada segmen perkantoran diduga didorong oleh infrastruktur yang semakin baik serta masih terdapat permintaan terutama dari perusahaan di bidang financial dan IT. Sedangkan secara tahunan, pertumbuhan indeks harga properti komersial melambat dari $1,37 \%$ (years of years) pada triwulan sebelumnya menjadi $0,32 \%$ (years of years) pada triwulan IV-2019 (Grafik 2). Perlambatan tersebut terutama disebabkan oleh penurunan harga pada segmen apartemen sewa dan perlambatan kenaikan harga lahan industri, convention hall dan pergudangan. Pada segmen apartemen sewa, penurunan mencapai $-1,61 \%$ (years of years) pada triwulan IV-2019, terkontraksi atau mengalami penurunan lebih dalam dibandingkan triwulan III-2019 yang mencapai $-1,19 \%$ (years of years). Sementara itu, harga lahan industri tercatat tumbuh $0,64 \%$ (years of years), melambat dari 1,69\% (years of years) pada triwulan sebelumnya, disebabkan transaksi yang relatif minim sehingga pasar lahan industri relatif tidak berubah. Pada convention hall pertumbuhan tercatat $3,45 \%$ (years of years), melambat dari $4,27 \%$ (years of years), pada triwulan sebelumnya, seiring kembali normalnya harga sewa pasca tingginya permintaan aktivitas pertemuan dalam rangka pemilihan presiden dan kongres partai politik.

Menurut Hartono (2014:392), informasi yang dipublikasikan perusahaan sebagai suatu pengumuman akan memberikan signal bagi investor dalam pengambilan keputusan investasi. Dengan adanya signaling theory menjelaskan bahwasannya terdapat alasan perusahaan memiliki keinginan untuk memberikan informasi laporan keuangan kepada pihak eksternal atau investor secara terbuka. Perusahaan mempunyai dorongan untuk memberikan informasi terbuka dengan tujuan adanya informasi yang tidak seimbang antara perusahaan dengan pihak eksternal. Hal ini dikarenakan perusahaan sudah mengetahui lebih banyak tentang sistem dan prospek perusahaan yang akan datang, dibandingkan dengan pihak eksternal. Salah satu upaya guna mengurangi informasi yang tidak seimbang dengan cara memberikan signal kepada pihak luar, seperti memberikan informasi keuangan secara triwulan ataupun tahunan yang bisa dipercaya dan akan mengurangi keraguan terhadap prospek perusahaan di masa yang akan datang.

Dari semua uraian ini, maka pada tulisan ini akan dilakukan penelitian tentang pengaruh debt to equity ratio, current ratio, dan earning per share terhadap beta saham. Pada penelitian ini akan dilakukan penilaian terhadap 17 sampel perusahaan yang memiliki kriteria tertentu di BEI untuk dilakukan pengukuran risiko yang dihadapi perusahaan tersebut, yang dapat berpengaruh terhadap return saham.

\section{Signaling Theory}

Signaling theory menjelaskan bahwasannya teori ini berguna untuk menggambarkan perilaku ketika kedua belah pihak (individu atau organisasi) yang memiliki akses menuju informasi ang berbeda. Biasanya pihak dari pengirim sinyal menggunakan caranya sendiri untuk berkomunikasi atau mengirimkan sinyal tersebut. Dari pihak lain atau penerima biasanya juga menggunakan cara sendiri untuk mengintepretasikan sinyal dari pengirim (Connel dkk, 2011).

\section{Debt to Equity Ratio}

Debt to equity ratio atau rasio hutang terhadap ekuitas yang berfungsi dengan tujuan yang hampir sama dengan rasio hutang terhadap total aset. Debt to equity ratio yaitu rasio total hutang dengan modal sendiri, merupakan perbandingan antara total hutang dengan modal sendiri atau ekuitas. Debt to equity ratio juga 
menunjukkan tingkat hutang perusahaan, perusahaan dengan hutang besar memiliki biaya yang lebih besar dari hutang (Van Horne \& Wachowicz Jr, 2014:169).

\section{Total Hutang \\ Ekuitas Pemegang Saham}

\section{Current Ratio}

Sesuai dengan apa yang dirumuskan oleh (Van Horne \& Wachowicz Jr, 2014:167) salah satu dari rasio likuiditas yang paling umum dan sering digunakkan adalah rasio lancar atau current ratio. Rasio lancar yaitu aset lancar yang dibagi dengan liabilitas jangka pendek. Rasio ini menunjukkan kemampuan perusahaan untuk membayar liabilitas jangka pendeknya dengan menggunakan aset lancarnya. Current Ratio yang tinggi memberikan indikasi jaminan yang baik bagi kreditor jangka pendek dalam arti setiap saat perusahaan memiliki kemampuan untuk melunasi kewajibankewajiban jangka pendeknya

\section{$\frac{\text { Aset Lancar }}{\text { Liabilitas Jangka Pendek }}$}

\section{Earning Per Share}

Earning Per Share (EPS) atau pendapatan per lembar saham adalah bentuk pemberian keuntungan yang diberikan kepada para pemegang saham dari setiap lembar saham yang dimiliki (Fahmi, 2014:83). Berdasarkan pendapat dari Fahmi, definisi pendapatan per lembar saham yang dimaksud dalam penelitian ini adalah ratio yang menunjukkan seberapa besar keuntungan yang diperoleh investor atau pemegang saham yang beredar selama satu periode. Jika kemampuan pendapatan per lembar saham perusahaan sangat tinggi, maka akan mempengaruhi risiko sistematis (sistematyc risk) saham. Karena pendapatan per lembar saham menunjukkan besarnya laba bersih perusahaan yang dibagikan untuk semua pemegang saham perusahaan. Perusahaan yang memiliki nilai EPS tinggi, sangat diharapkan akan memberikan keuntungan yang besar kepada investor.

$$
E P S=\frac{E A T}{J s b}
$$

\section{Beta Saham}

Risiko sistematik untuk suatu saham dapat diukur dengan cara menunjukkan koefisien beta. Beta saham mengukur kepekaan saham terhadap perubahan pasar. Semakin besar beta suatu saham menunjukkan semakin pekanya tingkat keuntungan suatu saham untuk bereaksi jauh melebihi perubahan tingkat keuntungan indeks pasar. Return dan risiko merupakan dua hal yang tidak terpisahkan, karena pertimbangan suatu investasi merupakan trade-off dari kedua faktor ini. Return dan risiko mempunyai hubungan yang positif, semakin besar risiko yang harus ditanggung, semakin besar return yang dikompensasikan (Hartono, 2014).

$$
\beta_{i}=\frac{\operatorname{Cov}\left(R_{i}, R_{M}\right)}{\operatorname{Var}\left(R_{M}\right)}
$$

\section{Kerangka Pemikiran}

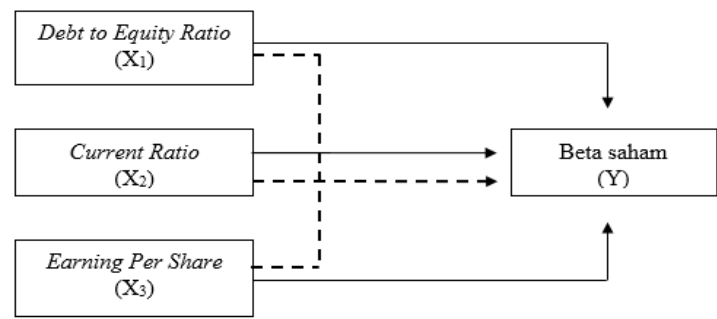

Gambar 1. Kerangka Pemikiran

Dimana :

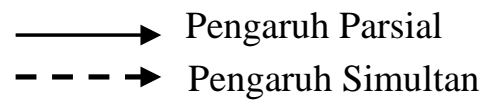

\section{Hipotesis Penelitian}

Dalam dugaan sementara dari permasalahan yang sudah dirumuskan sebagai berikut.

H1: Debt to equity ratio berpengaruh signifikan positif terhadap beta saham pada perusahaan sektor property and real estate di BEI periode 2010-2019.

H2: Current ratio berpengaruh signfikan positif terhadap beta saham pada perusahaan sektor property and real estate di BEI periode 2010-2019.

H3: Earning Per Share berpengaruh signfikan positif terhadap beta saham pada perusahaan sektor property and real estate di BEI periode 2010-2019.

H4: Debt to equity ratio, current ratio, dan earning per share berpengaruh signfikan dan positif secara simultan terhadap beta saham pada perusahaan sektor property and real estate di BEI periode 2010-2019. 


\section{METODE}

\section{Sumber Data Penelitian}

Data yang digunakan adalah data dari laporan keuangan tahunan dari 17 perusahaan selama 10 tahun. Selain dari laporan keuangan, juga menggunakan data menegenai harga saham per tahun dari setiap perusahaan. Semua data yang digunakan pada penelitian ini merupakan data sekunder, dimana laporan keuangan diperoleh dari sumber www.idx.co.id dan sumber dari harga saham per tahun www.yahoofinance.co.id serta sumber dari data indeks harga saham gabungan ialah www.ojk.go.id, dengan selama periode 2010-2019.

\section{Teknik Pengolahan Data}

Dalam pengolahan data terdapat teknik yaitu secara manual dan computerize. Pada penelitian ini menggunakan teknik secara computerize yang memakai program Eviews 10 . Eviews (Econometric Views) merupakan program komputer yang bisa digunakan untuk mengolah data statistik dan data ekonometri. Program ini juga dapat digunakan untuk menyelesaikan masalah atau data-data yang berupa time-series, cross section, dan data panel. Hal itulah yang menjadi landasan atau alasan untuk menggunakan program computer bernama Eviews 10. Karena data dari penelitian ini tergolong kedalam data panel, yang merupakan data suatu objek terdiri dari beberapa periode.

\section{HASIL DAN PEMBAHASAN}

\section{Hasil}

\section{Analisis Linier Berganda}

Analisis regresi linier pada penelitian ini menggunakan metode Random Effect Berikut ini merupakan tabel hasil pengujian regresi dengan metode Common Effect.

Berdasarkan hasil regresi di atas dapat diketahui bahwasannya nilai koefisien masingmasing variabel yang digunakan dalam persamaan regresi linier berganda. Berikut merupakan persamaan regresi linier berganda

Persamaan regresi di atas dapat diartikan sebagai berikut:

a. Konstanta $(\propto)$ sebesar 17.50538, artinya jika Debt to equity ratio (DER), Current ratio (CR), dan Earning Per Share (EPS) bernilai 0 atau tidak mengalami peningkatan dan penurunan, maka nilai dari beta saham adalah 17.50538.

b. Nilai koefisien regresi Debt to equity ratio (DER) sebesar -14.19819, yang artinya menunjukkan arah negatif (berlawanan arah) antara Debt to equity ratio (DER) dengan beta saham. Hal ini menandakan bahwa apabila variabel Debt to equity ratio (DER) mengalami kenaikan 1\%, maka beta saham akan turun sebesar -14.19819 dengan asumsi variabel lain nilainya tetap.

C. Nilai koefisien regresi Current Ratio (CR) sebesar -1.465034, dapat diartikan bahwa hasil ini menunjukkan arah yang negatif (berlawanan arah) antara Current Ratio (CR) dengan beta saham. Hal ini menandakan jika variabel Current Ratio (CR) mengalami kenaikan $1 \%$, maka beta saham akan mengalami penurunan sebesar 1.465034 dengan asumsi variabel lain nilainya tetap.

d. Nilai koefisien regresi Earning Per Share (EPS) sebesar -0.007899, dimana hal ini menunjukkan arah hubungan negatif (berlawanan arah) antara Earning Per Share (EPS) dengan beta saham. Hal ini menandakan bahwa apabila variabel Earning Per Share (EPS) mengalami kenaikan 1\%, maka beta saham akan turun sebesar 0.007899 dengan asumsi variabel lain nilainya tetap.

\section{Uji Hipotesis}

\begin{tabular}{|c|c|c|c|c|}
\hline Variable & Coefficient & Std. Error & t-Statistic & Prob. \\
\hline C & 17.50538 & 10.36781 & 1.688436 & 0.0932 \\
\hline X1_DER & -14.19819 & 7.140180 & -1.98 & 0.0484 \\
\hline X2_CR & -1.465034 & 2.127948 & -0.688473 & 0.4921 \\
\hline X3_EPS & -0.007899 & 0.011711 & -0.674497 & 0.5009 \\
\hline
\end{tabular}

Tabel 1. Hasil Uji t-statistic 


\section{Pengaruh Variabel Debt to equity ratio (DER) Terhadap Beta Saham}

Berdasarkan perhitungan statistic diperoleh nilai $\mathrm{t}$ hitung sebesar -1.988492 dengan menggunakan taraf signifikansi (Probabilitas) sebesar $\alpha=0.05 / 2$ (uji 2 sisi) dan derajat kebebasan ( $\mathrm{df}=\mathrm{n}-\mathrm{k}=170-4=166$ ), bahwa nilai t hitung sebesar $-1.988492<$ nilai $t$ tabel sebesar $(-1.988492<1.65408)$. Nilai negative pada t hitung menunjukkan bahwa debt to equity ratio (DER) mempunyai pengaruh negative terhadap beta saham.

\section{Pengaruh Variabel Current Ratio (CR) Terhadap Beta Saham}

Berdasarkan perhitungan statistic diperoleh nilai $t$ hitung sebesar -0.688473 dengan menggunakan taraf signifikansi (Probabilitas) sebesar $\alpha=0.05 / 2$ (uji 2 sisi) dan derajat kebebasan ( $\mathrm{df}=\mathrm{n}-\mathrm{k}=170-4=166$ ), bahwa nilai t hitung sebesar $-0.688473<$ nilai $t$ tabel sebesar $(-0.688473<1.65408)$. Nilai negative pada t hitung menunjukkan bahwa Current Ratio (CR) mempunyai pengaruh negative terhadap beta saham.

\section{Pengaruh Variabel Earning Per Share (EPS) Terhadap Beta Saham}

Berdasarkan perhitungan statistic diperoleh nilai $\mathrm{t}$ hitung sebesar -0.674497 dengan menggunakan taraf signifikansi (Probabilitas) sebesar $\alpha=0.05 / 2$ (uji 2 sisi) dan derajat kebebasan ( $\mathrm{df}=\mathrm{n}-\mathrm{k}=170-4=166$ ), bahwa nilai t hitung sebesar $-0.674497<$ nilai t tabel sebesar $(-0.674497<1.65408)$. Nilai negative pada t hitung menunjukkan bahwa earning per share (EPS) mempunyai pengaruh negative terhadap beta saham.

\section{Tabel 2. Hasil Uji F-statistic}

\begin{tabular}{lcll} 
R-squared & 0.023363 & Mean dependent var & 0.99 \\
Adjusted R-squared & 0.005712 & S.D. dependent var & 42.11 \\
S.E. of regression & 41.99768 & Akaike info criterion & 10.33 \\
Sum squared resid & 292791.6 & Schwarz criterion & 10.41 \\
Log likelihood & -874.5901 & Hannan-Quinn criter. 10.36 \\
F-statistic & 1.323651 & Durbin-Watson stat & 2.14 \\
Prob(F-statistic) & 0.268462 & & \\
\hline \hline
\end{tabular}

Hasil dari perhitumgan uji $\mathrm{F}$ menunjukkan bahwa secra bersama-sama variabel independen tidak berpengaruh terhadap variabel dependen.
Hal ini dibuktikan dengan adanya nilai F-statistic yaitu sebesar 1.323651 dengan dfl $(\mathrm{N} 1)=\mathrm{k}-1=4$ $-1=3$, dan df2 $(\mathrm{N} 2)=\mathrm{n}-\mathrm{k}=170-4=166$ yang diperoleh F-tabel sebesar 2.66, sehingga Fstatistic $<$ F-tabel $=1.323651<2.66$. Dengan demikian menunjukkan bahwa pengaruh debt to equity ratio, current ratio, dan earning per share berbanding terbalik terhadap beta saham atau dengan kata lain jika nilai pengaruh debt to equity ratio, current ratio, dan earning per share meningkat maka nilai beta saham akan menurun.

\section{Koefisien Determinasi}

Dapat disimpulkan koefisien determinasi (R-squared) yang ditunjukkan oleh nilai RSquared sebesar 0.023363 atau $2.34 \%$ yang menunjukkan bahwa kontribusi dari variabel independen yang terdiri dari debt to equity ratio, current ratio, dan earning per share terhadap variabel dependen yaitu beta saham sebesar $2.34 \%$ sisanya $(100 \%-2.34 \%=97.66 \%)$ dipengaruhi oleh variabel lain diluar model regresi, seperti variabel debt to equity ratio (DER) dan earning per share (EPS)

\section{Pembahasan}

\section{Pengaruh Debt to equity ratio terhadap beta saham}

Hasil pengujian diketahui bahwa secara parsial debt to equity ratio tidak berpengaruh terhadap beta saham pada perusahaan sektor property and real estate di BEI. Keadaan ini dapat dilihat dari hasil regresi yang menunjukkan dengan nilai thitung sebesar $-1.988492<$ nilai ttabel sebesar 1.65408. Tidak pengaruhnya debt to equity ratio terhadap beta saham dimungkinkan terjadi karena berapapun nilai besaran debt to equity ratio

\section{Pengaruh Current ratio terhadap beta saham}

Hasil pengujian diketahui bahwa secara parsial current ratio tidak berpengaruh terhadap beta saham pada perusahaan sektor property and real estate di BEI. Keadaan ini dapat dilihat dari hasil regresi yang menunjukkan dengan nilai thitung sebesar $-0.688473<$ nilai t-tabel sebesar 1.65408 .

Tidak berpengaruhnya current ratio terhadap beta saham dimungkinkan terjadi karena proses dalam likuiditas di perusahaan property and real estate memang cukup lama. Oleh sebab itu perusahaan sektor property and real estate tentu saja bersifat jangka panjang, sehingga hal ini bisa menandakan jika current ratio tidak mempunyai pengaruh terhadap beta saham di perusahaan property and real estate. 
Hal ini juga didasari dengan sifat data yang heterogen karena terdapat beberapa perusahaan yang sejenis, sehingga menjadikan ketidaksignifikannya current ratio terhadap beta saham. Karena masing - masing industri mempunyai tingkat kewajarannya sendiri, ada yang wajarnya bernilai tinggi dan ada yang bernilai rendah

\section{Pengaruh Earning Per Share terhadap beta saham}

Hasil pengujian diketahui bahwa secara parsial earning per share

tidak berpengaruh terhadap beta saham pada perusahaan sektor property and real estate di BEI. Keadaan ini dapat dilihat dari hasil regresi yang menunjukkan dengan nilai thitung sebesar $0.674497<$ nilai t-tabel sebesar 1.65408 .

Tidak pengaruhnya earning per share terhadap beta saham dimungkinkan terjadi karena memang earning per share secara fungsi hanya memberikan gambaran harga lembar persaham pada periode tertentu yang hanya memfokuskan investor kepada angka earning per share tanpa memperhatikan perusahaan secara keseluruhan, sehingga tidak memperoleh informasi mengenai sumber dan karakterisktik dari laba serta deviden. Maka berapapun besaran nilai dari earning per share

\section{Pengaruh Debt to equity ratio, Current ratio, dan Earning Per Share terhadap beta saham}

Hasil pengujian diketahui bahwa secara simultan Debt to equity ratio, Current ratio, dan Earning Per Share tidak berpengaruh terhadap beta saham pada perusahaan sektor property and real estate di BEI. Dari keadaan ini dapat dilihat dengan hasil regresi yang menunjukkan bahwa nilai signifikansi (probabilitas Fhitung) sebesar 0.268462 yang berarti tidak mengalami signifikansi $>0.05$ dengan nilai F-hitung sebesar $1.323651<$ nilai F-tabel 2.66.

\section{SIMPULAN DAN SARAN}

\section{Simpulan}

Penelitian ini bertujuan untuk menguji pengaruh Debt to equity ratio, Current ratio, dan Earning Per Share terhadap beta saham pada perusahaan sektor property and real estate di Bursa Efek Indonesia. Berdasarkan hasil penelitian, maka dapat diambil kesimpulan sebagai berikut:
1. Hasil pengujian secara parsial menunjukkan bahwa variabel debt to equity ratio tidak berpengaruh terhadap beta saham pada perusahaan sektor property and real estate di Bursa Efek Indonesia tahun 2010 s. d 2019.

2. Hasil pengujian secara parsial menunjukkan bahwa variabel current ratio tidak berpengaruh terhadap beta saham pada perusahaan sektor property and real estate di Bursa Efek Indonesia tahun 2010 s. d 2019

3. Hasil pengujian secara parsial menunjukkan bahwa variabel earning per share tidak berpengaruh terhadap beta saham pada perusahaan sektor property and real estate di Bursa Efek Indonesia tahun 2010 s. d 2019.

4. Hasil pengujian secara simultan menunjukkan bahwa variabel debt to equity ratio, current ratio, dan earning per share secara bersama-sama atau simultan tidak berpengaruh terhadap beta

\section{Saran}

Dalam berinvestasi perlu untuk memperhatikan kinerja perusahaan yang bisa dilihat dari laporan keuangan tahunannya guna mengetahui keadaan perusahaan baik dalam keadaan sehat atau berindikasi kesulitan keuangan dan prospek yang baik atau sebaliknya yang cenderung mengalami penurunan kinerja di masa depan. Perhitungan yang menggunakan rasio-rasio keuangan yang ada bisa membantu pihak investor untuk menilai keadaan perusahaan baik dari segi kesehatan maupun segi imbal hasil investasinya. Investor sebaiknya juga mempertimbangkan informasi-informasi keuangan yang lain seperti halnya dalam kondisi fundamental emiten dan faktor makro lainnya.

Peneliti berikutnya diharapkan perlunya meningkatkan beberapa indikator lain selain debt to equity ratio, current ratio, dan earning per share karena sangat dimungkinkan indikator lain yang tidak dimasukkan dalam penelitian ini bisa berpengaruh terhadap beta saham. Penggunaan model lainnya juga dianjurkan guna menghasilkan prediksi yang lebih dari penelitian saat ini dan alat bantu pengolahan data yang berbeda bisa dimungkinkan untuk hasil prediksi yang lebih baik juga.

\section{DAFTAR PUSTAKA}


Aji, R. S. (2015). Analisis Faktor-Faktor Yang Mempengaruhi Risiko Sistematis (Beta) Saham Pada Perusahaan Manufaktur Yang Terdaftar Di Bursa Efek Indonesia (BEI) periode 2009-2014. Diponegoro Journal Of Management, 1-15.

Ali Shah, S. (2020). Determinants of Systematic Risk in Commercial Banks of Pakistan. IJEFI, 125-129.

Atidhira, A. T., \& Yustina, A. I. (2015). The Influence of Return on Asset, Debt to Equity Ratio, Earnings per Share, and Company Size on Share Return in Property and Real Estate Companies. JAAF (Journal of Applied Accounting and Finance), Vol. 1. No. 2, page 128-146.

Connely, B., Cetro, S., Ireland, R., \& Reutzel, C. (2011). Signaling Theory: A Review and Assessment. Journal of Management , 37-39.

Fahmi, I. (2014). Manajemen Keuangan Perusahaan dan Pasar Modal. Jakarta: Mitra Wacana Media.

Fatihudin, D. (2017). Panduan Praktis Merencanakan Keuangan Untuk Investasi di Pasar Modal, Pasar Uang, dan Valas. Surabaya: UM Surabaya.

Fatihudin, D. (2020). Metodologi Penelitian. Sidoarjo: Zifatama.

Fatihudin, D., Jusni, \& Mochklas, M. (2018). HOW MEASURING FINANCIAL PERFORMANCE. International Journal of Civil Engineering and Technology, 553-557.

Firlika, R. (2014). Pengaruh Operating Leverage, Debt to equity ratio, Dan Current Ratio Terhadap Risiko Sistematis (Beta) Saham Pada Perusahaan Sub Sektor Makanan Dan Minuman Periode 2010-2013. e-Proceeding of Management, 122-137.

Handayani, D. W. (2014). Pengaruh Debt to equity ratio, Likuiditas, Pertumbuhan Asset, dan Ukuran Perusahaan terhadap Beta Saham Pada Perusahaan Manufaktur. JURNAL DINAMIKA AKUNTANSI DAN BISNIS, Vol. 1, No. 2, Hlm. 169-182.

Hartono, J. (2014). Teori Portofolio dan Analisis
Investasi (Edisi Ketiga). Yogyakarta: BPFE.

Hartono, J. (2016). Teori Portofolio dan Analisis Investasi (Edisi Kesepuuh). Yogyakarta: BPFE.

Jazuli, A. M., \& Witiastuti, R. S. (2016). Determinan Beta Saham Perusahaan Real Estate Dan Property Di Bei. Management Analysis Journal, 63-69.

Kusuma, I. L. (2016). Pengaruh Asset Growth, Debt To Equity Ratio, Return On Equity, Total Asset Turnover Dan Earning Per Share terhadap Beta Saham Pada Perusahaan yang Masuk dalam Kelompok Jakarta Islamic Index (JII) Periode 2013-2015. JURNAL RISET AKUNTANSI \& KEUANGAN, 1005-1020.

Priyatno, D. (2012). Belajar Cepat Olah Data Statistik Dengan SPSS. Yogyakarta: Penerbit Andi.

Puspitaningtyas, Z. (2017). Estimating Systematic Risk For The Best Investment Decisions On Manufacturing Company In Indonesia. Business Perspectives, 46-54.

Soeroso, A. (2013). Faktor Fundamental (Current Ratio, Total Debt to Equity Ratio, Total Asset Turnover, Return on Investment) Terhadap Risiko Sisitematis pada Industri Food and Beverages di Bursa Efek Indonesia. Jurnal, Vol.1, No.4. ISSN: 23031174.

Sugiyono. (2017). Metode Penelitian Bisnis. Bandung: Alfabeta.

Sukmaningrum, P. (2019). Factors Affecting Stock Beta Companies Listed in Jakarta Islamic Index 2012-2016 Period. Knowledge E Social Sciences, 264-284.

Van Horne, J. C., \& Wachowicz Jr, J. M. (2014). Fundamental of Financial Management. Jakarta: Salemba Empat.

Widarjono, A. (2007). Ekonometri: Teori dan Aplikasi Untuk Ekonomi dan Bisnis, edisi kedua. Yogyakarta: Ekonisia FE Universitas Islam Indonesia. 